\title{
The Current Status of Small Indigenous Fish Species (SIS) of River Gorai, a Distributary of the River Ganges, Bangladesh
}

\author{
Hanif MA ${ }^{1 *}$, Siddik MAB ${ }^{1}$, Nahar $A^{1}$, Chaklader MR ${ }^{1}$, Rumpa $\mathbf{R J}^{2}$, Alam $\mathbf{M J}^{3}$ and Mahmud $\mathbf{S}^{4}$
}

${ }^{1}$ Department of Fisheries Biology and Genetics, Patuakhali Science and Technology University, Patuakhali-8602, Bangladesh

${ }^{2}$ Department of Aquaculture, Bangladesh Agricultural University, Mymensingh-2202, Bangladesh

${ }^{3}$ Department of Fisheries Management, Patuakhali Science and Technology University, Patuakhali-8602, Bangladesh

${ }^{4}$ Department of Aquaculture, Patuakhali Science and Technology University, Patuakhali-8602, Bangladesh

\begin{abstract}
Small indigenous fish species (SIS) play a vital role in providing animal protein sources for human. The Gorai river, a Ganges tributary is a habitat of considerable number of SIS. A total of 11040 individual from 40 species were collected belonging 7 orders and 19 families using 5 fishing nets and 1 fish trap of which 2 species were critically endangered, 7 endangered, 7 species vulnerable, 18 species not threatened, 2 data deficient and 4 species were not in evaluated category. Dominant orders were Cypriniformes and Perciformes each contained 12 species, dominant family was Cyprinidae (11 species) and most dominant species was Chela cachius (2253 individuals). Diversity indices ranges from Simpson's dominance index (0.06-0.09), Simpson's index (0.91-0.94), Shannon Weiner index (3.08-3.24), Evenness (0.56-0.66), Menhinick's index (0.61-0.67), Margalef's index (4.48-4.77), Equitability (0.84-0.89) and Fisher alpha (5.86-6.31), respectively. Highest numbers (38) of SIS were caught by set bag net. Maximum total length $4.6 \mathrm{~cm}$ of Corica soborna was the new record. Considering the nutritional importance and reducing number of SIS inhabiting in the river Gorai, the present study aimed at documentation of SIS, their threatened status and conservation of SIS through laws and regulations.
\end{abstract}

Keywords: SIS; Relative abundance; Fishing gear; Conservation; Gorai river

\section{Introduction}

Small indigenous fish species (SIS) is denoted the species of fish which can grow to a maximum size of $25 \mathrm{~cm}$ or 9 inches in their mature or adult stage of lifecycle [1]. About 260 indigenous freshwater fish species are available in Bangladesh of which 143 has been reported as SIS. These species have been considered as an excellent source of essential protein, macro and micro-nutrients, vitamins and minerals, which can play a significant role in the fulfilment of nutritional deficiency in human being [2]. Some SIS like Puntius sp. comprises double quantity of iron compared to various cultured carps such as Hypophthalmichthys molitrix and Labeo rohita and SIS Amblypharyngodon mola contains three times more calcium and fifty times vitamin-A than that of $H$. molitrix and L. rohita [3]. A large number of SIS are still existing in various water bodies including rivers, beels, khals, haors, baors etc of Bangladesh but their existence is at stake in almost every water bodies due to indiscriminate catching of SIS by numerous baleful fishing gears leading SIS to a high risk of extinction.

Gorai River is one of the major distributaries of the river Ganges that serves as an important habitat for fisheries particularly of SIS. A very few study is conducted where baseline information about the abundance and distribution of SIS is available [4,5]. Measuring bio-assessment have become a commonly shared tool to assess the ecological compliant and to detect the impacts to aquatic creatures in the river systems $[6,7]$. Aquatic biodiversity is now under austere stress throughout the world and SIS is not exceptional of them. Studies estimated to about $39 \%$ of all freshwater species of aquatic ecosystem are extinct, endangered, or vulnerable worldwide [8]. Nearly $20 \%$ of freshwater fish species is now either facing endangered or extinct condition worldwide. A huge number of small indigenous species of fishes are now under threatened condition due to frequent decline in the water area of Bangladesh but there is a lack of concern over this constant decline of SIS biodiversity. Systematic understanding of numerous management policies to conserve biodiversity, fish abundance accompanied by their natural distribution is crucial to back up their optimum exploitation [9-12]. To know the fish diversity in the water is prerequisite before undertaking any fisheries management tools [13]. Diversity index provides more information than simply the amount of species present in a particular water body which acts as an important tool that gives vital information on scarcity and commonness of species in a community [14]. Taking into account of human nutrition, ecological balance, sustainability of SIS and healthy aquatic environment a comprehensive assessment of SIS is indispensable from every water resources. However, considering future prospects of SIS in Bangladesh, the present study was aimed to focus on the diversity, seasonal abundance, impacts of fishing gears and conservation of SIS in the river Gorai, Bangladesh.

\section{Materials and Methods}

\section{Study area}

The study was conducted in the river Gorai, a distributary of the Ganges river situated in the mid-western part of Bangladesh (Figure 1). Three sampling stations were selected for the present study located between latitude $23^{\circ} 40^{\prime}$ to $23^{\circ} 55^{\prime}$ north and longitude $89^{\circ} 03^{\prime}$ to $89^{\circ} 20^{\prime}$ east. Geographical locations of each sampling stations are shown in Table 1.

*Corresponding author: Abu Hanif Md, Department of Fisheries Biology and Genetics, Patuakhali Science and Technology University, Patuakhali-8602, Bangladesh, Tel: +91450965212; E-mail: mdabuhanif01@gmail.com

Received April 30, 2016; Accepted June 08, 2016; Published June 15, 2016

Citation: Hanif MA, Siddik MAB, Nahar A, Chaklader MR, Rumpa RJ et al. (2016) The Current Status of Small Indigenous Fish Species (SIS) of River Gorai, a Distributary of the River Ganges, Bangladesh. J Biodivers Endanger Species 4 162. doi: $10.4172 / 2332-2543.1000162$

Copyright: $\odot 2016$ Hanif MA, et al. This is an open-access article distributed unde the terms of the Creative Commons Attribution License, which permits unrestricted use, distribution, and reproduction in any medium, provided the original author and source are credited. 


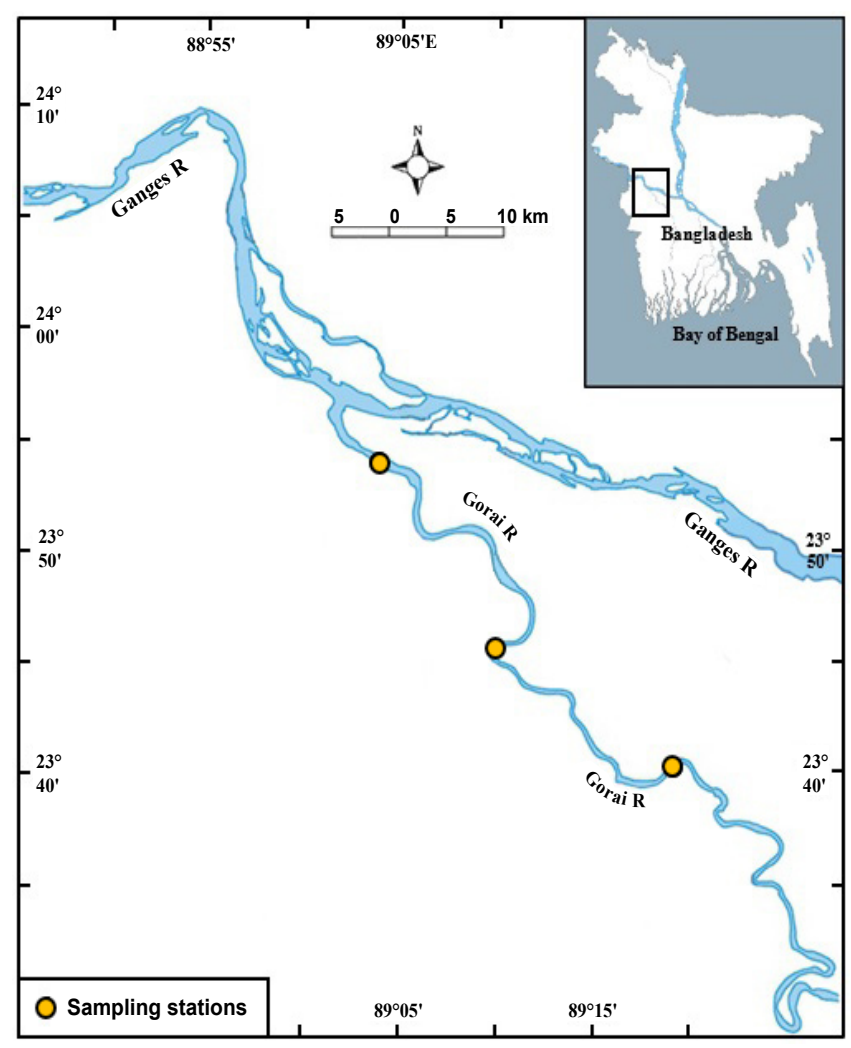

Figure 1: Sampling sites in the Gorai River.

\begin{tabular}{|c|c|c|c|}
\hline Sampling station & $\begin{array}{c}\text { Name of sampling stations } \\
\text { (District) }\end{array}$ & Latitude & longitude \\
\hline Station 1 & Kushtia & $23^{\circ} 53^{\prime}$ & $89^{\circ} 03^{\prime}$ \\
\hline Station 2 & Jhenaidaha & $23^{\circ} 44^{\prime}$ & $89^{\circ} 12^{\prime}$ \\
\hline Station 3 & Rajbari & $23^{\circ} 40^{\prime}$ & $89^{\circ} 19^{\prime}$ \\
\hline
\end{tabular}

Table 1: Geographical location of SIS sampling stations.

\section{Data collection}

Small indigenous fish species (SIS) were collected from sampling stations during June 2014 to January 2015 by using different fishing gears which were available in the study areas. Required data were collected monthly in daytime. Instinctive knowledge of fishermen from study areas and previous information [15-17] indicates that catch size shows a significant difference in a lunar month. Data such as species diversity, seasonal abundance of SIS, fishing gear used were collected by using PRA technique (Focus group discussion) among the fishermen (Fishing all day long) community adjacent to the Gorai river.

\section{Collection and identification of SIS samples}

Fish collected from the sampling stations were preserved with $10 \%$ formalin for further identification based on their morphometric and meristic characters following [18] and [19]. After identification, fish species were systematically classified according to [20].

\section{Diversity indices}

To quantify the diversity of the assemblage and for the statistical comparison of the diversity at three different stations of the study area following diversity index; Simpson dominance index (D), Shannon Weiner index $(\mathrm{H})$, Evenness index, Menhinick's index, and Fisher alpha were calculated. Simpson's dominance index, $D=\Sigma\left(\left(n_{i} / n\right)^{2}\right)$; Where, $\mathrm{n}$ is the total number of individuals and $\mathrm{n}_{\mathrm{i}}$ is number of individuals of taxon I; Shannon index, $H=-\Sigma\left(\left(n_{\mathrm{i}} \mathrm{n}\right) \ln \left(\mathrm{n}_{\mathrm{i} /} \mathrm{n}\right)\right.$; Buzas and Givson's evenness $=\mathrm{e}^{\mathrm{H}} / \mathrm{S}$; where, $\mathrm{S}$ is the number of taxa, Menhinick's index = $\mathrm{S} / \sqrt{ } \mathrm{n}$; Fisher's alpha $=\mathrm{a} \times \ln (1+\mathrm{n} / \mathrm{a})$; Where, $\mathrm{a}$ is the fisher's alpha.

\section{Data analysis}

All statistical analyses were done using Microsoft Excel 2013 and PAST (PAleontological STatistics) package version 3.10.

\section{Results}

The present study documented 40 species of SIS from Gorai river belonging to 7 orders and 19 families during the study period. Family Cyprinidae comprised the highest 8 SIS and nearest family Bagridae and Schilbeidae contained 3 SIS and remaining families comprised less than 3 species within the documented 40 SIS which are summarized in order of availability through the study period in Table 2 .

Within the recorded 7 orders, Perciformes was the most dominant contributing 8 families (40.00\%) followed by Siluriformes 4 families (20.00\%), Beloniformes, Clupeiformes, Cypriniformes each contributed 2 families (10.00\%) and least dominant order was Osteoglossiformes and Synbranchiformes each contributing 1 family (5.00\%) (Table 2). In case of species, dominant order was Cypriniformes and Perciformes both comprised 12 species (30.00\%) whereas nearest order Siluriformes which encompasses 8 species $(20.00 \%)$ followed by Clupeiformes 3 species (7.5\%), Beloniformes, synbranchiformes each contained 2 species $(5.00 \%)$ and least order was Osteoglossiformes comprised only 1 species (2.50\%) (Figure 2). The catch composition varies according to different season. Some species were available in monsoon that were not seen in monsoon or other seasons such as X. cancila, N. nandus and A. gagora found large number in monsoon while D. pusilla, N. notopterus, M. tengara and C. garua found small number in monsoon season. Similarly, some species were available in winter that were not observed in monsoon or other seasons; for instance C. neglecta, A. bato and $O$. pabda largely available in winter while M.. Elanga, B. badis, E. fusca, $H$. fossilis and $M$. pancalus were found small number in winter season. Although certain species were found throughout the year (TY) either in large amount (LTY) or small amount (STY) but some species were very rare ${ }^{*}$ ) including O. cotio, P. chola, S. sarana, P. ticto, E. danricus, B. dario, A. testudineus, B. badis, L. guntea, C. gachua, C. punctatus, M. vittatus, C. garua, S. silondia and H. fossilis. Most common $\left.{ }^{* * *}\right)$ species either found in large or small amount including C. neglecta, G. chapra, C. soborna, A. mola, C. cachius, P. sophore, A. bato and M. aculeatus while some species were found in rare ${ }^{* *}$ (Table 2).

A total of 11040 individuals were captured of 40 SIS from three sampling stations and maximum 37 fishes were recorded from station 1, 33 from station 2 and 34 SIS fishes from station 3. Out of 40 SIS fishes, 16 species were threatened according to IUCN, Bangladesh 2000 including 2 critically endangered (5.13\%), 7 endangered (17.95\%) and 7 vulnerable (17.95\%). Other categories contributed to $46.15 \%$ not threatened, $10.26 \%$ not evaluated and rest $2.56 \%$ data deficient (Figure 3). The minnows constituted maximum $34.16 \%$ of the whole relative abundance followed by cat fishes $22.48 \%$; Perches $6.36 \%$, eel $4.97 \%$, snake head 0.65 and others contributes a large portion $31.4 \%$ (Figure $4)$.

Maximum total length of SIS were between the ranges of 2-25 cm and maximum number of fishes captured were between the length of $5-20 \mathrm{~cm}$, while maximum number of SIS grow to a length between 2-25 $\mathrm{cm}$ but some author reported that some species of fishes can grow up 
Citation: Hanif MA, Siddik MAB, Nahar A, Chaklader MR, Rumpa RJ et al. (2016) The Current Status of Small Indigenous Fish Species (SIS) of River Gorai, a Distributary of the River Ganges, Bangladesh. J Biodivers Endanger Species 4: 162. doi:10.4172/2332-2543.1000162

Page 3 of 8

\begin{tabular}{|c|c|c|c|c|c|c|c|}
\hline \multirow[b]{2}{*}{ Order } & \multirow[b]{2}{*}{ Family } & \multirow[b]{2}{*}{ Species } & \multirow[b]{2}{*}{ English name } & \multirow[b]{2}{*}{ Status } & \multirow[b]{2}{*}{ Seasonal availability } & \multicolumn{2}{|c|}{ Maximum Length (cm) } \\
\hline & & & & & & Author's record & $\begin{array}{l}\text { Reported } \\
\text { (Fishbase) }\end{array}$ \\
\hline \multirow{2}{*}{ Beloniforrmes } & Belonidae & $\begin{array}{l}\text { Xenentodon cancila (Hamilton, } \\
\text { 1822) }\end{array}$ & Freshwater garfish & NT & $* *$, LM & 13.4 & 17 \\
\hline & Zenarchopteridae & $\begin{array}{l}\text { Dermogenys pusilla (Kuhl \& van } \\
\text { Hasselt, 1823) }\end{array}$ & Halfback & NE & ${ }^{* *}, \mathrm{SM}$ & 5.8 & 7 \\
\hline \multirow{3}{*}{ Clupeiformes } & Engraulidae & Coilia neglecta (Whitehead, 1967) & $\begin{array}{l}\text { Neglected grenadier } \\
\text { anchovy }\end{array}$ & NE & ${ }^{* * *}, \mathrm{LW}$ & 15.1 & 17 \\
\hline & Clupeidae & Gudusia chapra (Hamilton, 1822) & Indian river shad & NT & $* * *, T Y$ & 16.2 & 20 \\
\hline & & Corica soborna (Hamilton, 1822) & Ganges river sprat & NE & $* * *$, STY & 4.6 & 4.1 \\
\hline \multirow{12}{*}{ Cypriniformes } & Cyprinidae & $\begin{array}{l}\text { Amblypharyngodon mola } \\
\text { (Hamilton, 1822) }\end{array}$ & Mola carplet & NT & ${ }^{* * *}, \mathrm{TY}$ & 7.8 & 20 \\
\hline & & Labeo bata (Hamilton, 1822) & Bata labeo & EN & ${ }^{* *}, \mathrm{STY}$ & 18.2 & 25 \\
\hline & & Chelon parsia (Hamilton, 1822) & Goldspot mullet & NT & STY & 13 & 16 \\
\hline & & $\begin{array}{l}\text { Osteobrama cotio (Hamilton, } \\
\text { 1822) }\end{array}$ & Cotio & EN & * & 9.4 & 15 \\
\hline & & Puntius chola (Hamilton, 1822) & Green berb & NT & * & 7 & 15 \\
\hline & & Chela cachius (Hamilton, 1822) & Silver hatchet & DD & ${ }^{* * *}, \mathrm{TY}$ & 4.1 & 6 \\
\hline & & $\begin{array}{l}\text { Systomus sarana (Hamilton, } \\
\text { 1822) }\end{array}$ & Olive berb & CR & * & 19.6 & 42 \\
\hline & & Puntius sophore (Hamilton, 1822) & Pool berb & NT & $* * \star, T Y$ & 12.9 & 20 \\
\hline & & Pethia ticto (Hamilton, 1822) & Ticto berb & VU & * & 4.1 & 10.2 \\
\hline & & $\begin{array}{l}\text { Esomus danricus (Hamilton, } \\
\text { 1822) }\end{array}$ & Flying berb & NT & * & 8.5 & 13 \\
\hline & & $\begin{array}{l}\text { Megarasbora. Elanga (Hamilton, } \\
\text { 1822) }\end{array}$ & Bengala berb & EN & ${ }^{* *}, \mathrm{SW}$ & 12.2 & 21 \\
\hline & Cobitidae & Botia dario (Hamilton, 1822) & Bengal loach & EN & * & 10.2 & 15.1 \\
\hline Osteoglossiformes & Notopteridae & $\begin{array}{l}\text { Notopterus notopterus (Pallas, } \\
\text { 1769) }\end{array}$ & Bronze featherback & VU & ${ }^{* *}, \mathrm{SM}$ & 19.4 & 60 \\
\hline \multirow{12}{*}{ Perciformes } & Ambassidae & Chanda nama (Hamilton, 1822) & Elongate glass-perchlet & VU & **, STY & 4.1 & 11 \\
\hline & & $\begin{array}{l}\text { Parambassis ranga (Hamilton, } \\
\text { 1822) }\end{array}$ & Indian glassy fish & VU & ${ }^{* *}$, STY & 2.7 & 8 \\
\hline & Anabantidae & Anabas testudineus (Bloch, 1792) & Climbing perch & NT & * & 8.3 & 25 \\
\hline & & Badis badis (Hamilton, 1822) & Blue perch & EN & *, SW & 2.2 & 5 \\
\hline & Cobitidae & $\begin{array}{l}\text { Lepidocephalichthys guntea } \\
\text { (Hamilton, 1822) }\end{array}$ & Guntea loach & NT & * & 8.7 & 10.4 \\
\hline & Gobiidae & Apocryptes bato (Hamilton, 1822) & Mudskipper & NT & $* * *, L W$ & 16.4 & 26 \\
\hline & & $\begin{array}{l}\text { Glossogobius giuris (Hamilton, } \\
\text { 1822) }\end{array}$ & Tank goby & NT & TY & 23.9 & 50 \\
\hline & Belontidae & $\begin{array}{l}\text { Trichogaster fasciata (Bloch \& } \\
\text { Schneider, 1801) }\end{array}$ & Striprd gourami & NT & $* *$ & 6.2 & 12.5 \\
\hline & Channidae & Channa gachua (Hamilton, 1822) & Asiatic snakehead & VU & * & 15.6 & 20 \\
\hline & & Channa punctate (Bloch, 1793) & Spotted snakehead & NT & * & 16.1 & 30 \\
\hline & Eleotridae & Elotris fusca (Forster, 1801) & Dusky sleeper & NE & ${ }^{* \star}, \mathrm{SW}$ & 6.3 & 17 \\
\hline & Nandidae & Nandus nandus (Hamilton, 1822) & Mud perch & VU & ${ }^{* *}, \mathrm{LM}$ & 10.1 & 20 \\
\hline \multirow{8}{*}{ Siluriformes } & Bagridae & Arius gagora (Hamilton, 1822) & Gagora catfish & DD & ${ }^{* *}, \mathrm{LM}$ & 13.8 & 20.7 \\
\hline & & Mystus tengara (Hamilton, 1822) & Tengra mystus & NT & ${ }^{* *}, \mathrm{SM}$ & 7.9 & 18 \\
\hline & & Mystus vittatus (Bloch, 1794) & Striped river catfish. & NT & * & 9.1 & 21 \\
\hline & Schilbeidae & Ailia coila (Hamilton, 1822) & Gangetic ailia & VU & LTY, LW & 12.3 & 15.4 \\
\hline & & $\begin{array}{l}\text { Clupisoma garua (Hamilton, } \\
\text { 1822) }\end{array}$ & Garua bachcha & $\mathrm{CR}$ & *, SM & 23.3 & 60.9 \\
\hline & & Silonia silondia (Hamilton, 1822) & Silond catfish & EN & * & 20.6 & 80 \\
\hline & Siluridae & Ompok pabda (Hamilton, 1822) & Pabdah catfish & EN & ${ }^{* *}, \mathrm{LW}$ & 13.1 & 30 \\
\hline & Heteropneustidae & $\begin{array}{l}\text { Hateropneustes fossilis (Bloch, } \\
\text { 1794) }\end{array}$ & Stinging catfish & NT & *, sw & 17.6 & 30 \\
\hline \multirow{2}{*}{ Synbranchiformes } & Mastacembelidae & $\begin{array}{l}\text { Macrognathus aculeatus (Bloch, } \\
\text { 1786) }\end{array}$ & Lesser spiny eel & NT & ${ }^{* * *}, \mathrm{TY}$ & 15.8 & 38 \\
\hline & & $\begin{array}{l}\text { Mastacembelus } \\
\text { armatus (Lacepède, 1800) }\end{array}$ & Zig-zag eel & NT & ${ }^{* *}, \mathrm{SW}$ & 13.2 & 18 \\
\hline
\end{tabular}

CR, critically Endangered, EN, Endangered, VU, Vulnerable, Status in the IUCN Red List according to IUCN Bangladesh (2000), NT, Not threatened, DD, Data deficient, NE, Not evaluated, ${ }^{* * *}$, Common; ${ }^{* *}$, Rare; *, Very rare; LM, Large amount in monsoon; SM, Small amount in monsoon; SW, Small amount in winter; TY, Throughout the year; LTY, Large amount throughout the year, STY, Small amount throughout the year.

Table 2: List of SIS, their status, availability and maximum length in the Gorai River 

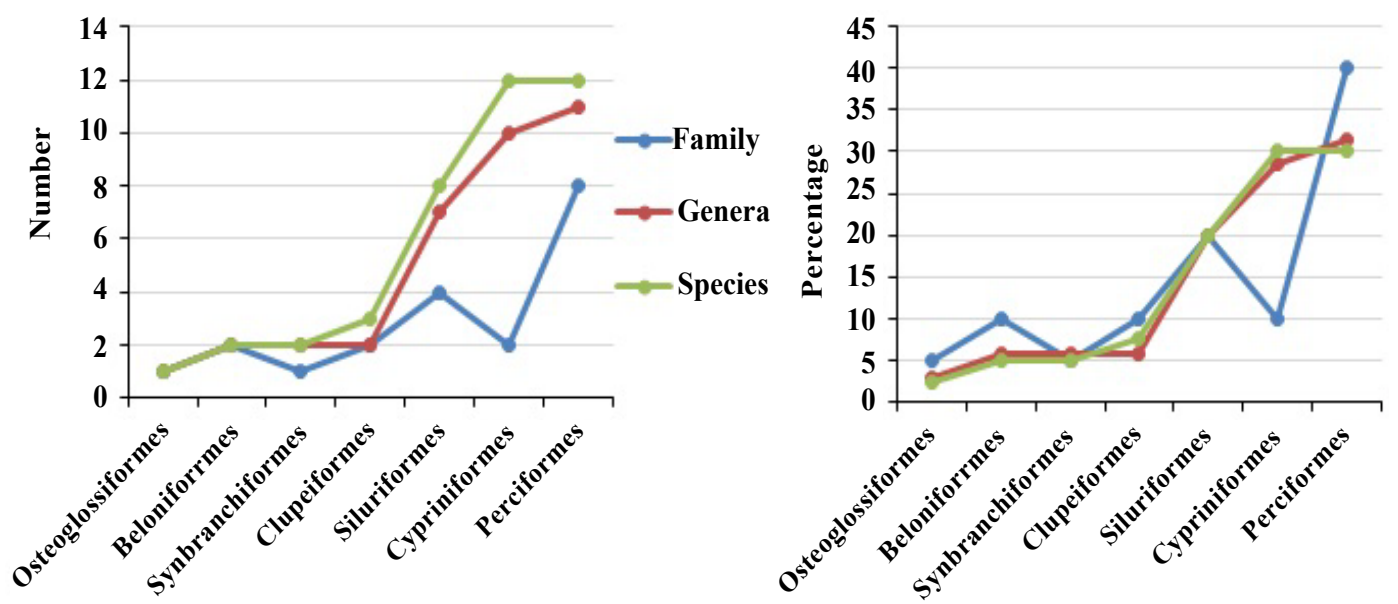

Figure 2: Number and percent composition of families, genera and species of SIS under various orders recorded in the Gorai River.

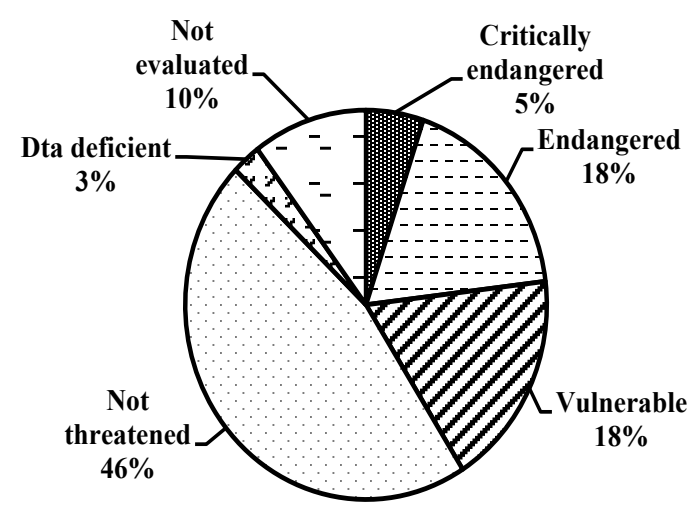

Figure 3: Conservation status of SIS under different categories

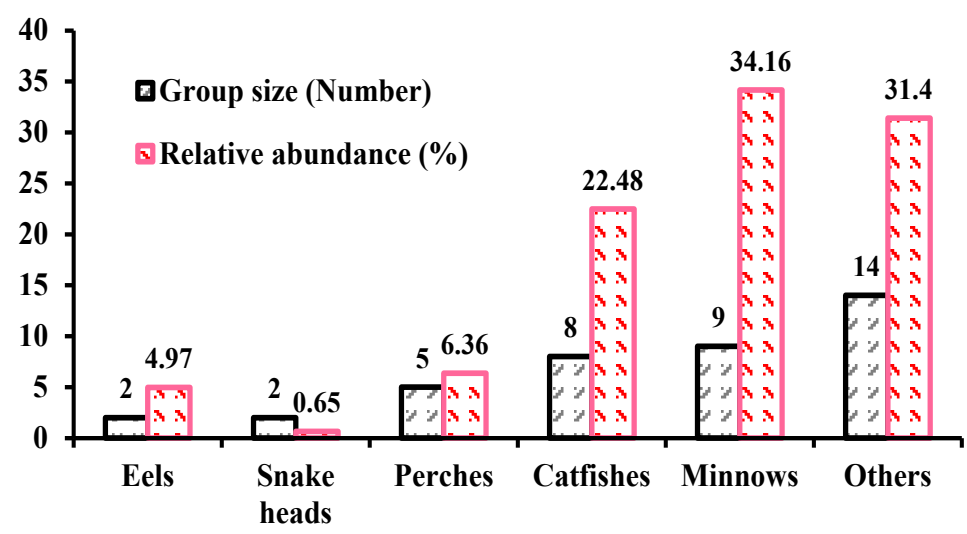

Figure 4: Size and relative abundance of common groups of SIS.

to $80 \mathrm{~cm}$ (Table 2, Figure 5). Other than Ganges river sprat (Corica soborna) that attained a maximum total length $4.6 \mathrm{~cm}$, all species total length (recorded by author) were lower than the maximum length reported (Fishbase report) by different scientists (Figure 5).

Maximum 4800 individuals of 38 species were captured by set bag net which is about $43.48 \%$ of total catch during the study period while 1707, 1044, 702, 2241 and 546 individuals were caught through using cast net, gill net, push net, lift net and trap respectively (Table 3) which was about $20.30 \%, 15.46 \%, 9.46 \%, 6.36 \%$ and $4.95 \%$ of total catch (Figure 6).

\section{Biodiversity indices}

In order to know the diversity status of SIS, Simpson dominance index (D), Simpson index (1-D); Shannon Weiner index (H); Evenness, 
Citation: Hanif MA, Siddik MAB, Nahar A, Chaklader MR, Rumpa RJ et al. (2016) The Current Status of Small Indigenous Fish Species (SIS) of River Gorai, a Distributary of the River Ganges, Bangladesh. J Biodivers Endanger Species 4: 162. doi:10.4172/2332-2543.1000162

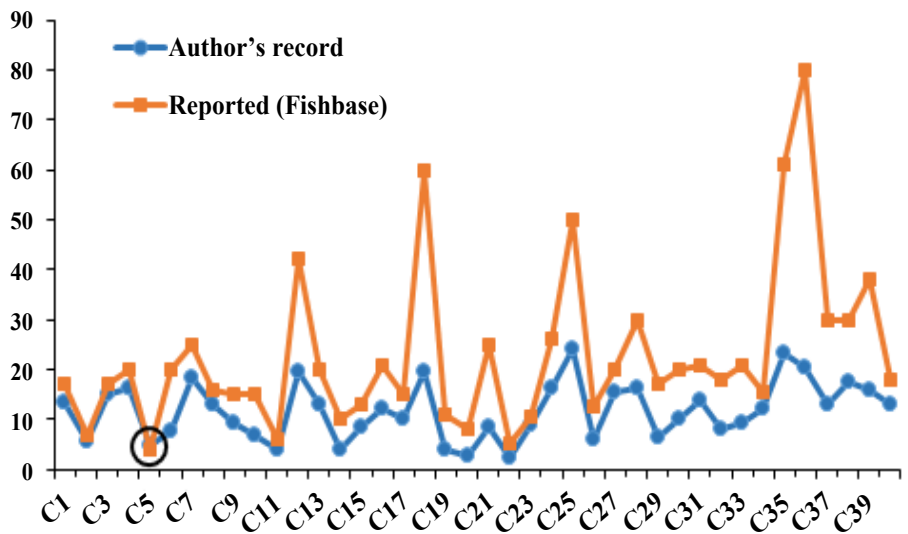

Figure 5: Maximum total length of SIS of collected sample by author vs. reported total length.

\begin{tabular}{|c|c|c|c|c|c|c|c|c|c|c|c|c|}
\hline \multirow{2}{*}{ Species } & \multirow{2}{*}{$\begin{array}{l}\text { Specis } \\
\text { code }\end{array}$} & \multicolumn{6}{|c|}{ Number of SIS caught by fishermen } & \multicolumn{3}{|c|}{ Individuals catch } & \multirow{2}{*}{ Total } & \multirow{2}{*}{$\%$} \\
\hline & & Set bag net & Cast net & Push net & Gill net & Lift net & Trap & St. 1 & St. 2 & St. 3 & & \\
\hline Xenentodon cancila & $\mathrm{C} 1$ & 48 & 117 & 24 & 0 & 54 & 6 & 127 & 52 & 70 & 249 & 2.26 \\
\hline Dermogenys pussilus & $\mathrm{C} 2$ & 327 & 0 & 78 & 0 & 33 & 0 & 203 & 88 & 147 & 438 & 3.97 \\
\hline Coilia neglecta & $\mathrm{C} 3$ & 183 & 69 & 21 & 9 & 57 & 39 & 162 & 119 & 97 & 378 & 3.42 \\
\hline Gudusia chapra & $\mathrm{C} 4$ & 114 & 12 & 0 & 96 & 63 & 0 & 106 & 94 & 85 & 285 & 2.58 \\
\hline Corica soborna & C5 & 189 & 81 & 15 & 0 & 117 & 0 & 137 & 112 & 153 & 402 & 3.64 \\
\hline $\begin{array}{c}\text { Amblypharyngodon } \\
\text { mola }\end{array}$ & $\mathrm{C} 6$ & 75 & 159 & 33 & 0 & 123 & 9 & 149 & 153 & 97 & 399 & 3.61 \\
\hline Labeo bata & $\mathrm{C} 7$ & 48 & 18 & 0 & 9 & 21 & 0 & 38 & 31 & 27 & 96 & 0.87 \\
\hline Chelon parsia & $\mathrm{C} 8$ & 21 & 57 & 0 & 36 & 24 & 21 & 46 & 51 & 62 & 159 & 1.44 \\
\hline Osteobrama cotio & $\mathrm{C9}$ & 66 & 78 & 12 & 0 & 117 & 15 & 117 & 92 & 79 & 288 & 2.61 \\
\hline Puntius chola & C10 & 24 & 33 & 21 & 87 & 54 & 18 & 87 & 55 & 95 & 237 & 2.15 \\
\hline Chela cachius & $\mathrm{C} 11$ & 1446 & 72 & 57 & 0 & 678 & 0 & 696 & 981 & 576 & 2253 & 20.41 \\
\hline Systomus sarana & C12 & 12 & 0 & 3 & 18 & 0 & 6 & 12 & 9 & 18 & 39 & 0.35 \\
\hline Puntius sophore & C13 & 93 & 18 & 48 & 33 & 72 & 24 & 67 & 79 & 142 & 288 & 2.61 \\
\hline Pethia ticto & C14 & 18 & 3 & 0 & 0 & 27 & 12 & 13 & 24 & 23 & 60 & 0.54 \\
\hline Esomus danricus & C15 & 12 & 24 & 3 & 0 & 51 & 0 & 38 & 31 & 21 & 90 & 0.82 \\
\hline Megarasbora. elanga & C16 & 6 & 39 & 0 & 0 & 72 & 0 & 47 & 38 & 32 & 117 & 1.06 \\
\hline Botia dario & C17 & 0 & 0 & 0 & 0 & 9 & 0 & 6 & 0 & 3 & 9 & 0.08 \\
\hline Notopterus notopterus & C18 & 18 & 3 & 0 & 9 & 0 & 0 & 0 & 13 & 17 & 30 & 0.27 \\
\hline Chanda nama & C19 & 219 & 12 & 24 & 0 & 51 & 0 & 93 & 102 & 111 & 306 & 2.77 \\
\hline Parambassis ranga & $\mathrm{C} 20$ & 42 & 0 & 0 & 0 & 27 & 0 & 29 & 23 & 17 & 69 & 0.63 \\
\hline Anabas testudineus & $\mathrm{C} 21$ & 12 & 3 & 0 & 48 & 0 & 6 & 26 & 13 & 30 & 69 & 0.63 \\
\hline Badis badis & $\mathrm{C} 22$ & 21 & 12 & 39 & 0 & 0 & 0 & 35 & 16 & 21 & 72 & 0.65 \\
\hline $\begin{array}{l}\text { Lepidocephalichthys } \\
\text { guntea }\end{array}$ & $\mathrm{C} 23$ & 51 & 6 & 3 & 0 & 42 & 18 & 51 & 43 & 26 & 120 & 1.09 \\
\hline Apocryptes bato & $\mathrm{C} 24$ & 63 & 309 & 171 & 0 & 0 & 33 & 168 & 187 & 221 & 576 & 5.22 \\
\hline Glossogobius giuris & $\mathrm{C} 25$ & 54 & 78 & 36 & 0 & 6 & 54 & 82 & 69 & 77 & 228 & 2.07 \\
\hline Trichogaster fasciata & $\mathrm{C} 26$ & 111 & 45 & 6 & 18 & 81 & 9 & 101 & 92 & 77 & 270 & 2.45 \\
\hline Channa gachua & $\mathrm{C} 27$ & 0 & 6 & 6 & 0 & 0 & 27 & 0 & 21 & 18 & 39 & 0.35 \\
\hline Channa punctatus & $\mathrm{C} 28$ & 15 & 6 & 0 & 0 & 0 & 12 & 9 & 16 & 8 & 33 & 0.3 \\
\hline Elotris fusca & $\mathrm{C} 29$ & 36 & 18 & 96 & 0 & 51 & 24 & 68 & 82 & 75 & 225 & 2.04 \\
\hline Nandus nandus & $\mathrm{C} 30$ & 51 & 18 & 21 & 57 & 12 & 27 & 69 & 73 & 44 & 186 & 1.68 \\
\hline Arius gagora & $\mathrm{C} 31$ & 156 & 84 & 9 & 39 & 96 & 6 & 142 & 109 & 139 & 390 & 3.53 \\
\hline Mystus tengara & $\mathrm{C} 32$ & 129 & 36 & 12 & 27 & 57 & 0 & 94 & 80 & 87 & 261 & 2.36 \\
\hline Mystus vittatus & $\mathrm{C} 33$ & 78 & 12 & 0 & 36 & 27 & 18 & 62 & 51 & 58 & 171 & 1.55 \\
\hline Ailia coila & $\mathrm{C} 34$ & 234 & 24 & 0 & 96 & 12 & 0 & 121 & 133 & 112 & 366 & 3.32 \\
\hline Clupisoma garua & $\mathrm{C} 35$ & 78 & 12 & 0 & 18 & 33 & 6 & 57 & 48 & 42 & 147 & 1.33 \\
\hline Silonia silondia & $\mathrm{C} 36$ & 111 & 36 & 6 & 12 & 18 & 0 & 59 & 60 & 64 & 183 & 1.66 \\
\hline Ompok pabda & $\mathrm{C} 37$ & 372 & 78 & 204 & 54 & 126 & 39 & 315 & 269 & 289 & 873 & 7.91 \\
\hline Hateropneustes fossilis & $\mathrm{C} 38$ & 12 & 42 & 3 & 0 & 0 & 33 & 21 & 37 & 32 & 90 & 0.82 \\
\hline Macrognathus aculeatus & C39 & 174 & 57 & 42 & 0 & 18 & 69 & 138 & 116 & 106 & 360 & 3.26 \\
\hline Mastacembelus armatus & $\mathrm{C} 40$ & 81 & 30 & 51 & 0 & 12 & 15 & 54 & 63 & 72 & 189 & 1.71 \\
\hline
\end{tabular}

Table 3: Catch composition of SIS in different fishing gears operated by fishermen in the Gorai River. 


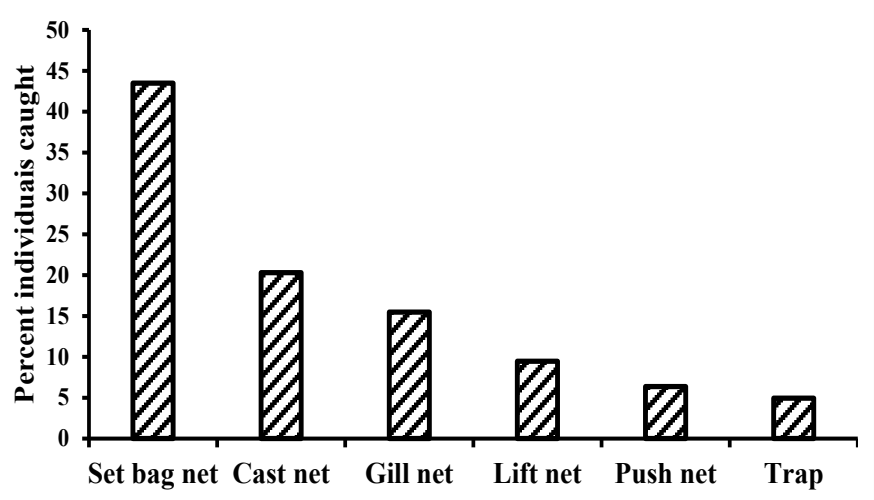

Figure 6: Percent individuals of SIS of fish caught by different fishing gear.

\begin{tabular}{|c|c|c|c|}
\hline \multirow{2}{*}{ Diversity indices } & Station 1 & Station 2 & Station 3 \\
\cline { 2 - 4 } & $\mathrm{S}=38, \mathrm{n}=3845$ & $\mathrm{~S}=39, \mathrm{n}=3725$ & $\mathrm{~S}=40, \mathrm{n}=3556$ \\
\hline Simpson's dominance index & 0.06 & 0.09 & 0.06 \\
\hline Shannon Weiner index & 3.22 & 3.08 & 3.24 \\
\hline Evenness & 0.66 & 0.56 & 0.64 \\
\hline Menhinick's index & 0.61 & 0.64 & 0.67 \\
\hline Fisher alpha & 5.86 & 6.07 & 6.31 \\
\hline
\end{tabular}

Table 4: Diversity indices of SIS in the Gorai River.

Menhinick's index, Margalef's index, Equitability and Fisher alpha were calculated according to sampling station (Table 4). After polling entire samples, the Simpson's dominance index (D) was found to be between 0.06-0.09 and the highest value (0.09) was found in station 2 whereas rest two station showed same and lowest value (0.06). Shannon Weiner index $(\mathrm{H})$ was ranged from 3.08-3.24 where highest value (3.24) was found in sampling station 3 and lowest (3.08) was in the station 2 . The value of evenness was between 0.56-0.66 while highest and lowest value was observed in station 1 and 2 respectively. In case of Menhinick's index, the value were ranged from 0.61-0.67 where highest (0.67) and (0.61) lowest value was in sampling station 3 and 1 individually. The value of fisher alpha were found between 5.86-6.31 while highest and lowest value was observed in sampling station 3 and 1 respectively.

\section{Discussion}

The maiden study on small indigenous species (SIS) from Ganges tributary, Gorai River, Bangladesh documented a total 40 SIS fishes under 7 orders and 20 families which was much lower as 260 freshwater fishes are available in the water areas of Bangladesh of which 143 species of fishes are reported as SIS. Due to insufficient statistical data on SIS on this river, no comparison was possible of the present study with previous one. Such type of common problem indicates the requirement of water body specific fish diversity study with a view to document all fish species of a country [21] documented 30 species of SIS fishes under 7 orders and 15 families during working on biodiversity of SIS in the river and adjacent beels of Karimgang which was more or less similar with the findings of present study but the present findings was much lower that reported by [4]. Cypriniformes, Perciformes and Siluriformes was the most dominant order in the study areas and [14] reported the similar findings during working on fish diversity in the coastal water of Bangladesh. Dominancy of these three orders of freshwater bodies of Bangladesh was also reported by [18]. Species of the order Osteoglossiformes is very lower compared to other orders. The family Cyprinida comprised the maximum number compared to other family due to presence of favorable environmental condition and river bottom which is preferred by the member of this family. The similar findings were observed by [21-23] reported the dominancy of Ciprinidae family during working on biodiversity of SIS in the river and adjacent beels of Karimgang and on the Atrai River in Naogaon district. The species Chela cachius was the most dominant species in three sampling stations. In the past, SIS were abundant in the water resources of Bangladesh including rivers, beels, pond, lakes, haors, baors, floodplains, stream etc but at present these species of fish are very rare and are in the way of extinction as they cannot breed or reproduce naturally due to habitat and environmental degradation. Thirteen species of SIS were rarely found in the study areas including Osteobrama cotio, Puntius chola, Systomus sarana, Puntius sophore, Pethia ticto, Botia dario, Anabas testudineus, Badis badis, Lepidocephalichthys gunte, Channa gachua, Channa punctatus, Mystus vittatus, Clupisoma garua, Silonia silondia, and Hateropneustes fossilis of which Systomus sarana and Clupisoma garua were critically endangered. Beside this, 7 species were endangered including Labeo bata, Osteobrama cotio, Megarasbora. Elanga, Botia dario, Badis badis, Silonia silondia, Ompok pabda and 7 species were vulnerable including Pethia ticto, Notopterus notopterus, Chanda nama, Parambassis ranga, Channa gachua, Nandus nandus and Ailia coila. A species of fish generally facing threatened condition owing to habitat degradation, mortality, indiscriminate catch, unsuccessful breeding due to pollution, predation, presence of chemicals in water sources and environmental change. Availability of SIS were decreasing day by day due to use of huge amount of fishing gear notably restricted gill net (Current jal) during winter when water depth reduced to minimum level. During this time fishermen used their fishing gear more effectively so that fish diversity generally highest in winter season [12]. A strong management approach is badly needed in this river otherwise this threatened species will be extinct within a short period from this geographical area. It is clear that $46 \%$ of SIS of fishes is not threatened till now so from the present situation resources user must be careful about catching SIS of fishes so that they can get a sustainable production year after year. There is a contradiction with the definition of SIS as some species of fishes are registered as SIS but they can grow to a maximum size more than $25 \mathrm{~cm}$ including Systomus sarana, Notopterus notopterus, Apocryptes bato, Glossogobius giuris, Channa punctatus, Clupisoma garua, Silonia silondia, Ompok pabda, Hateropneustes fossilis, Macrognathus aculeatus etc. Beside the Corica soborna, reported total length (Fish base) of all other SIS of fishes were higher than recoded by author as total length of Corica soborna was recorded $4.6 \mathrm{~cm}$ where reported total length was $4.1 \mathrm{~cm}$ (Table 2). Most catchment areas were station 1 which may be due to close contact with the mouth of Ganges River.

As SIS of fishes were very small, the set bag net (SBN) showed the highest number of species and individuals caught. The set bag net fishery was categorized with high degree of fishing mortality also with large omnivory indices on behalf of the most commercially exploited groups including demersal and pelagic [24] . It is clear that set bag net is more harmful as almost all size of SIS were caught by this net because of its different mesh size and if this net are frequently used in this river, within a short period some threatened species will be disappeared specially Systomus sarana, Clupisoma garua, Botia dario, Silonia silondia etc. The mesh size of cast net ranged from 2.2"-2.5" and with this mesh size more than $50 \%$ of the major fish species caught which is also responsible for frequent decline of SIS. [25] Reported that $56 \%$ by number of the major fish species caught in this fishery. In general gill net showed the maximum catch size but the mesh size was fixed and that allows easily escape of small size fish species from the mesh of gill net. Gillnets have relatively higher discard rates compared to traps is likely to be extensively applicable to aquatic systems having diverse 
Citation: Hanif MA, Siddik MAB, Nahar A, Chaklader MR, Rumpa RJ et al. (2016) The Current Status of Small Indigenous Fish Species (SIS) of River Gorai, a Distributary of the River Ganges, Bangladesh. J Biodivers Endanger Species 4: 162. doi:10.4172/2332-2543.1000162

Page 7 of 8

assemblage of fish species, as use of gillnet is based on target fish species usually has poor by catch rates of non-target species while fishing traps select equally on fish size and feeding preferences [26,27]. The increasing numbers of lift net has intensified the fishery dramatically and are said to have had a destructive effect on the ecosystem [28], although the effects of lift net and push net are comparatively lower for the present study.

There is a burning question of defining and selecting systems for biodiversity assessment that is still focus extensively and strongly polemic [29-36]. Diversity index provides vital information about the rarity and commonness of a species in a community and is an essential tool for biologists to understand community structure. A biodiversity index seeks to characterize the diversity of a sample or community of a single number [37]. Shannon Wiener diversity index reissues the richness as well as amount of every species but evenness and Simpson's dominance index describe the relative number of individuals in the sample and the portion of common species respectively. Simpson's dominance index is commonly used to calculate the biodiversity of a particular habitat. The partial variation of Simpson's dominance index summarized in Table 4 may be due to the temporal difference of dominance status among the sampling stations. Shannon Weiner index value typically ranges from 1.5-3.5 for ecological data that can hardly exceed 4.0 [38] and it can be above 5.0 when the samples hold 1,00,000 species [39]. The calculated value of the present study for diversity assessment of SIS of fishes was between the typical ranges (3.08-3.24). Evenness refers to the closeness in number of each species and the evenness value of sampling station mentioned in Table 4 indicate that station 1 and 3 were more even in number than station 3. Menhinick's index is a measure of species richness and has no limit value, its variation occur depending on the number of species. Menhinick's index value was higher in station 3 because of maximum number of species (SIS) were available in this station so station 3 was more species richness than others two. Menhinick's index is accredited to reduced number of species and environmental deprivation as a result of anthropogenic forces, in addition to other biotic factors [40]. Fisher's alpha log series predicts the number of species at different levels of abundance that is used as a measure of diversity. Higher the Fisher's alpha value (increase in geometric way) higher the species abundance in a level but has no limit value. Fisher's alpha value was higher in station 3 that means station 3 were more diversified than station 1 and 2 in case of SIS of fishes.

Conservation of biodiversity is very essential to maintain the sustainability of ecosystem and to support the maximum yield of living resources. Understanding spatial and temporal patterns in fish species assemblage structure is precarious for the conservation and management of indigenous fish [41,42]. Small indigenous species (SIS) of fishes in this river are decreasing day by day which may be due to overexploitation, habitat lose [43], pollution, illegal fishing gear used etc. and it may be in future due to environmental impact (climate change). Morphological studies [44] with ecology and fishery biology studies are greatly recommended for effective conservation of SIS of fishes. A proposed conservation recommendation includesmonitoring of environmental impact on fishery biology, strictly obey the laws and regulation of catch composition, fishing time and fishing gear used, awareness building among the resource user on sustainable catch and pollution control, stock assessment and establishment of fish sanctuary in some part of Gorai River. The declaration of some part of this river as fish protected areas can be an imperative step for the conservation of SIS of fishes and their biodiversity. Continuous research work on creating the biography of threatened SIS of fishes in the river is essential for effective conservation [37]. Permissible and institutional improvements are essential to involve local people in in-situ conservation and participate the decorative fish industry in universal conservation $[45,46]$. Restocking threatened SIS of fish, establishing fish sanctuaries, using destructive fishing gear and over fishing should be strictly prohibited, establishing community based organizations (CBOs) for proper management of water bodies, regular dredging specific points of rivers, identification and protection of spawning and nursery grounds, motivating people to integrated pest management (IPM) system to decrease the use of harmful chemicals fertilizers and pesticides [38] also highly recommended for conservation of SIS.

\section{Conclusion}

The result of present study is an outline of the biodiversity of small indigenous species (SIS), their availability, threatened status and the effects of fishing gear operated in the Gorai river. A total 143 species is termed as SIS in Bangladesh of which 40 species in a river is of course very low abundance. As SIS provide required amount of vitamin and minerals in human body, so considering their nutritional value, such type of small fish production need to be increased through culture and conservation. Overfishing using illegal fishing gears and fishing during spawning season should be strictly prohibited; using hazardous chemicals (insecticides and pesticides) should be avoided by rising awareness among the resource users. Threatened SIS should be brought under culture condition for their existence, in nature protected areas declaration can be an effective measure through restoration of unavailable and threatened species in different season throughout the country. A gross study on SIS all over the country is crucial to know their diversity status so as to know either this number of SIS become constant or gradually change its number by increasing or decreasing.

\section{References}

1. Felts RA, Rajts F, Akhteruzzaman M (1996) Small Indigenous Fish Species Culture in Bangladesh $\mathrm{p}-41$.

2. Thilsted SH, Ross N, Hasan N (1997) The role of small indigenous fish species in food and nutrition security in Bangladesh, NAGA Newsletter p-13.

3. Villif A, Jorgensen LB (1993) Analysis of naeringgsstoffat I, in An Environmenta Monitoring System for GOLDA project: CARE - Bangladesh Interim Report.

4. Kostori FA, Parween S, Islam MN (2011) Availability of small indigenous species (SIS) of fish in the Chalan Beel - the largest wetland of Bangladesh. Univ J Zool Rajshahi Univ 30: 67-72.

5. Sharker M R, Siddik MAB, Nahar A, Shahjahan M, Faroque AA (2015) Genetic differentiation of wild and hatchery populations of Indian major carp Cirrhinus cirrhosis in Bangladesh. J. Environmen. Biol 36: 1223-1227.

6. Tejerina-Garro FL, Maldonado M, Ibanez C, Pont D, Roset N, et al. (2005) Effects of natural and anthropogenic environmental changes on riverine fish assemblages: a framework for ecological assessment of rivers. Brazilian Arc Biol Tech 48: 91-108.

7. Flinders CA Horwitz RJ, Belton $T$ (2008) Relationship of fish and macroinvertebrate communities in the mid-Atlantic uplands: Implications for integrated assessments. Ecol Ind 8: 588-598.

8. IUCN Bangladesh (2000) Red book of threatened fishes of Bangladesh, IUCN The world conservation union. pp. 12-116.

9. Fu C, Wu J, Chen J, Wu Q, Lei G (2003) Freshwater fish biodiversity in the Yangtze River basin of China: patterns, threats and conservation. Bio Cons 12: $1649-1685$.

10. Sharker MR, Mahmud S, Siddik MAB, Alam MJ, Alam MR (2015a) Livelihood status of hilsha fishers around Mohipur Fish Landing site, Bangladesh. World Journal of Fish and Marine Sciences 7, 2: 77-81.

11. Eros T, Scmera D (2010) Spatio-temporal scaling of biodiversity and the species time relationship in a stream fish assemblage. Fresh Biol 55: 2391 2400. 
Citation: Hanif MA, Siddik MAB, Nahar A, Chaklader MR, Rumpa RJ et al. (2016) The Current Status of Small Indigenous Fish Species (SIS) of River Gorai, a Distributary of the River Ganges, Bangladesh. J Biodivers Endanger Species 4: 162. doi:10.4172/2332-2543.1000162

12. Rao JCS, Raju CS, Simhachalam G (2014) Biodiversity and conservation Status of fishes of river Sarada, Visakhapatnam District, Andhra Pradesh, India. Res J Ani, Vet Fish Sci 2: 1-8.

13. Huda ATMN, Shah MS, Hasanuzzaman AFM, Azam MR (2009) An investigation on the ichthyofauna of the Gorai-Modhumati river system. Bangladesh $\mathrm{J}$ Zool 37: 11-24.

14. Hanif MA, Siddik MAB, Chaklader MR, Nahar A, Mahmud S (2015a) Fish diversity in the southern coastal waters of Bangladesh: present status, threats and conservation perspectives. Croatian J Fish 73: 148-161.

15. Hossain MAR, Nahiduzzaman M, Saha D (2012) Threatened fishes of the world: Puntiussarana (Hamilton 1822). Env Biol Fish 87: 197-198.

16. Chaklader MR, Nahar A, Siddik MAB, Sharker R (2014) Feeding habits and diet composition of Asian Catfish Mystus vittatus (Bloch, 1794) in Shallow Water of an Impacted Coastal Habitat. World J. Fish Mar. Sci 6: 551-556.

17. Siddik MAB, Nahar A, Ahamed F, Masood Z, Hossain MY (2013) Conservation of critically endangered Olive Barb Puntius sarana (Hamilton, 1822) through artificial propagation. Our Nature 11: 96-104.

18. Rahman AKA (2005) Freshwater Fishes of Bangladesh, second edition Zoological Society of Bangladesh, University of Dhaka, Dhaka, Bangladesh p. 263.

19. Eschmeyer WN (2014) Catalog of Fishes electronic version (ed.).

20. Nelson JS (2006) Fishes of the World, fourth edition. John Wiley \& Sons Inc p 601.

21. Jahan R, Quaiyum MA, Sarkar BS, Hossain MB, Jaman KMKB, et al. (2014) Biodiversity and seasonal abundance of Small Indigenous Fish Species (SIS) in the Rivers and adjacent beels of Karimgang (Kishoregang, Bangladesh). Asisn J Anim Sci 8: 38-46.

22. Joadder MAR (2012) A comprehensive study on the availability of fishes and Non-Fin Fishes in Atrai River of Naogaon District: A Case Study in Northern Part of Bangladesh. J Fish Int 7: 42-45.

23. Ahsan ME, Siddik MAB, Sharker MR, Alam MA, Nahar A, et al. (2014) Fish species availability in the fish landing centers of Patuakhali, Bangladesh. Int $J$ Sci Tec Res 3: 2, 1-6.

24. Nabi MRU, Ullah MH (2012) Effects of Set Bagnet fisheries on the shallow coastal ecosystem of the Bay of Bengal, Ocean \& Coastal Management 67 $75-86$.

25. Seisay MDB (1998) The cast net fishery Kainji lakie Nigeria, 1970-1997. Nigerian-German Kainji Lake Fisheries Promotion Project, Technical Report Series 12. ISSN: 1119-1449.

26. Vander Haegen, GE, Yi KW, Dixon JF, Ashbrook CE (2002) Commercial Selective Harvest of Coho Salmon and Chinook Salmon on the Willapa River using Tangle Nets and Gill Nets. Final report IAC Contract 01-1018N. Washington, Department of Fish and Wildlife.

27. Shester GG, Micheli F (2011) Conservation challenges for small-scale fisheries: Bycatch and habitat impacts of traps and gillnets, Biological Conservation 144: 1673-1681.

28. WorldFish (2001) An Institutional Analysis of Sasi Laut in Maluku, Indonesia ISBN- 9832346010, 9789832346012' p-327.

29. Siddik MAB, Nahar A, Ahamed F, Hossain MY (2014) Over-wintering growth performance of mixed-sex and mono-sex Nile tilapia Oreochromis niloticus in northeastern Bangladesh. Croatian Journal of Fisheries 72: 70-76.

30. Siddik MAB, Hanif MA, Chaklader MR, Nahar A, Mahmud S (2015) Fishery biology of gangetic whiting Sillaginopsis panijus (Hamilton, 1822) endemic to Ganges delta, Bangladesh. Egypt. J. Aquat. Res 41: 307-313.
31. Gotelli NJ, Colwell RK (2010) Estimating species richness. pp. $39-54$ in: Biological Diversity: Frontiers in Measurement and Assessment. A.E. Magurran and B.J. McGill (eds.). Oxford University Press, Oxford. p 345.

32. Hoffmann S, Hoffmann A (2008) Is there a "true" diversity? Ecol Econ 65: 213 215

33. Mérigot B, Gaertner JC (2011) Incorporation of phylogeny in biological diversity measurement: Drawbacks of extensively used indices, and advantages of quadratic entropy. Bioessays 33: 819-822.

34. Mouchet M, Villéger S, Mason M, Mouillot D (2010) Functional diversity measures: an overview of their redundancy and their ability to discriminate community assembly rules. Func Ecol $24: 867-876$.

35. Tuomisto H (2010) A consistent terminology for quantifying species diversity? Yes, it does exist. Oecologia 164: 853-860.

36. Gorelick R (2011) Commentary: Do we have a consistent terminology for species diversity? The fallacy of true diversity. Oecologia 167: 885-888.

37. Sarkar UK, Pathak AK, Sinha RK, Sivakumar K, Pandian AK (2012) Freshwate fish biodiversity in the River Ganga (India): changing pattern, threats and conservation perspectives. Rev Fis Biol Fish 22:251-272.

38. Hanif MA, Siddik MAB, Chaklader MR, Mahmud S, Nahar A, et al. (2015b) Biodiversity and Conservation of Threatened Freshwater Fishes in Sandha River, South West Bangladesh. World Appl Sci J 33: 1497-1510.

39. May RM (1975) Patterns of species abundance and diversity. In Ecology and Evolution of Communities (ed. M. L. D. Cody, J. M.). Cambridge, Mass.: Harvard University Press

40. Ravera O (2001) A comparison between diversity, similarity and biotic indices applied to the macroinvertebrate community of a small stream: The Ravella river (Como Province, Northern Italy). Aquatic Ecol 35: 97-107.

41. Jackson DA, Peres-Neto PR, Olden JD (2001) What controls who is where in freshwater fish communities the roles of biotic, abiotic, and spatial factors Canadian J Fish Aqua Sci 58: 157-170.

42. Wright KK, Li JL (2002) From continua to patches: examining stream community structure over large environmental gradients. Canadian Journal of Fisheries and Aquatic Sciences 59: 1404-1417.

43. Siddik M, Chaklader M, Hanif M, Islam M, Sharker M, et al. (2016) Stock Identification of Critically Endangered Olive Barb, Puntius sarana(Hamilton, 1822) with Emphasis on Management Implications. J Aquac Res Development 7: 411

44. Siddik MAB, Hanif MA, Chaklader MR, Nahar A, Fotedar R (2016) A multivariate morphometric investigation to delineate stock structure of gangetic whiting, Sillaginopsis panijus (Teleostei: Sillaginidae). SpringerPlus 5: 520.

45. Pethiyagoda R (2006) Conservation of Sri Lankan Freshwater Fishes. The Fauna of Sri.

46. Chaklader MR, Siddik MAB, Nahar A (2015) Taxonomic diversity of paradise threadfin Polynemus paradiseus (Linnaeus, 1758) inhabiting southern coastal rivers in Bangladesh. Sains Malaysiana 44: 1241-124. 